\title{
The Manifestation of Classism in the Astro Boy Animation
}

\author{
Yessi Ratna Sari ${ }^{1, *}$, Genta Iverstika Gempita ${ }^{2}$ \\ AMIK Mitra Gama ${ }^{1}$, Universiti Kebangsaan Malaysia ${ }^{2}$ \\ *Corresponding author. Email: yessiratnasari91@gmail.com
}

\begin{abstract}
Utopia is an appropriate word to describe about the ideal, worthy, and perfect life depicted in a city called Metro City in the Astro Boy animation. This study examines the animation movie Astro Boy and how the world that is being told in the works could be defined as Utopian world like it is being described through the movie. The purpose of this study is to proof whether the setting successfully conveyed the Utopian world or whether it still has some deficiency as Utopian is known as impossibly perfect world to be created. The corpus of this study is the movie of Astro Boy focuses on the setting and relationship between human kind and robots. This research uses a qualitative descriptive method which describes social phenomena by conducting in-depth understanding and analysis. The aims of this research is to analyze more deeply the picture contained in the animation, which shows how humans and robots are able to create a new world also coexist. Moreover, the conceptual framework that will be use is the theory of Capitalism and Classism in order to examine the setting of Utopian world.
\end{abstract}

Key words. Utopia, utopian world, classism, capitalism, Astro Boy

\begin{abstract}
Abstrak. Utopia adalah kata yang tepat untuk menggambarkan kehidupan yang ideal, layak, dan sempurna yang digambarkan di kota bernama Metro City dalam animasi Astro Boy. Studi ini membahas film animasi Astro Boy dan bagaimana dunia yang diceritakan dapat didefinisikan sebagai dunia utopis seperti yang digambarkan melalui film. Tujuan dari studi ini adalah untuk membuktikan apakah keadaan dan fenomenanya berhasil menyampaikan dunia utopis atau apakah masih memiliki beberapa kekurangan karena utopis dikenal sebagai dunia yang mustahil untuk diciptakan. Korpus dari penelitian ini adalah film Astro Boy yang berfokus pada fenomena dan hubungan antara manusia dengan robot. Penelitian ini menggunakan metode deskriptif kualitatif yang mendeskripsikan fenomena sosial dengan melakukan pemahaman dan analisis yang mendalam. Tujuan dari penelitian ini adalah untuk menganalisis lebih dalam gambaran yang terdapat pada animasi, yang menunjukkan bahwa manusia dan robot dapat menciptakan dunia baru serta hidup berdampingan. Selain itu, kerangka konseptual yang akan digunakan adalah teori kapitalisme dan klasisme untuk mengkaji fenomena dunia utopis.
\end{abstract}

Kata kunci. Utopis, dunia utopis, klasisme, kapitalisme, Astro Boy

\section{Introduction}

The story from animation genre is normally created from human imagination as representing in creating the new world that is mostly utopian world. It is the world that only has happiness. It is because human kind has an infinite imagination for their own world, such as creating the world that they want or creating what kind of life that they want to live. By using technology, people can create the realization of their imagination into an art, as if they live in that world. It means that the animation world is the representation of people's dream, their dream 
about life, world, or even another human being, like want to be a superhero or having supernatural power.

One of Japanese television animes which reflects about human life is Astro Boy. It started from the science fiction story created by Osamu Tezuka. Astro Boy is one of animation from Japan that is embracing the utopian possibilities for the future. It is because the author got influenced by the war and dreaming to live in the world where there only has happiness. The word of utopia has been used in the modern age to evoke imaginary lands, regions, nations, and socio-political projects. Introduced to general discourse by Thomas Moore five hundred years ago, the term was brought into play to refer to an imagined place or state of perfection, a "no-place" (literal translation of the Greek) that contrasted with known places (Parra \& Walsh, 2016). The book Utopia by Thomas Moore depicts an ideal place which was used ever since to define perfect societies wanted by people and promised by politicians (Abdelbaky, 2016). The utopia only exists on human's imagination. They want a life like in a paradise, just want a peaceful and perfect life. We can not find it in reality but in literary works.

Briefly about the story of Astro Boy is about a scientist, who has lost his child, namely Toby Tenma, and then creates a robot called Atom as a surrogate child. A brief about Astro Boy, Toby Tenma died in a young age because of the accident in the lab and his father creates a robot and transfer the memory of Toby into the robot. He created the fictional character of Astro (originally named as Atom), the robot who has a human heart is willing to help people and the world. Yet, even though the robot looks like Toby along with his memory and his attitude, but he is still not Toby. Since his father (the creator) could not accept the difference between his late son and the robot. The robot is being forced to leave and find his place in another place. However, even though he found the new place, he is still could not fit in since he is different from the other normal robots in general.

There were two settings in the story, they are Metro City and The Surface. Metro City is described as a place like a paradise that is floating in the sky. The robots do all human activities such as shopping, serving, taking care of things and doing any other important thing that was supposedly a human's work. Meanwhile The Surface is the opposite of Metro City. However, both cities has similar attitude towards the robots. Robots were created to do human tasks, treat them like slaves make them as a source of money and power.

A study on Japanase Society: Where Humans and Robot coexist proves that humans and robots can be friends (Takagi, 2020). They help humans' work, communicate and entertaine them too. It can be seen in the habits of the Japanese people. They love to attract with robots and believe that robots help people. An example is Astro Boy which appeared in 1960 and animated to TV. It is said that robots are used as helpers in everyday life as well as Astro, who eventually becomes a symbol of heroism that fights evil.

Utopian world as the ideal life arises from human dissatisfaction with the real world. They want equality between the rich and the poor. A world where all looks equal and fair. All can have the same thing, common property as well as the officials are elected by public. A science fiction of Verne is the story occurred in the United States during the Civil War (Qin, 2017). The world is called as Mysterious Island that appear from Verne's fantasy. The situation between the island and the situation during the war were different like heaven and hell.

In Astro Boy, there are othering, classism, slavery, and unhomeliness. Capitalism is often thought of as an economic system in which private actors own and control property in accord with 
their interests, and demand and supply freely set prices in markets in a way that can serve the best interests of society (Jahan \& Mahmud, 2015). It means that since there is the robot as the slave, then the human kind is defines as capitalist society. Because the human is subordinated to the laws of the market, in the movie the market use robot as the slave and having their own laborers, which means that the human have their own laborers that is the robots.

Moreover, in the previous research of capitalism in the novel The Great Gatsby narrates of social class that influences the characters (Leiwakabessy, 2020). They are Bourgeoisies and Proletariat, the upper and the lower class. Tom, Jordan Baker, Daisy and Nick were born as Bourgeoisies. George and Myrtle Wilsons are portrait of Proletariat, while Jay who was born to a poor family, could achieve his dream of rising to the upper class. These social classes reflect to behavior and attitude of someone. It can tell whether they have a high education or not. The higher a person's class, the treatment they got is also different, such in social or workplace. In the novel, it is told that people always live to have fun every time. The opportunities should use well to reach the desire in their life.

This can also be found in the health inequality case study that reveals the higher the likes of the prestige/rewards/security/authority/autonomy of people's jobs the better their chances of sustained good health and longevity (Scambler, 2019). There is a social class that discriminates against and differentiates treatment between the upper and lower classes.

The problems of this research are defined in the form of two questions; (1) Is Astro Boy represent the ideal of Utopian World and how can we find a narrative of utopian world from the story of Astro Boy? (2) Is there any other narrative apart from utopian world?

\section{Method}

Research method that is being used in this research is qualitative descriptive. Qualitative descriptive is a term used in qualitative research for a descriptive study. This type of research is generally used in social phenomenology (Yuliani, 2018) and it can be found in Astro Boy's story. The qualitative method commonly emphasizes deeper understanding aspects by using data interpretation and analysis. A qualitative approach aims to 'interpret' how the social world is experienced and understood by individuals within their social context (Dooly \& Moore, 2017).

In the present study, data were in the form of video clip whose total duration was 86 minutes taken from YouTube https://www.youtube.com/watch?v=OuWGQFC-cD8 titled Astro Boy. The utterances were orthographically transcribed with as much detail and thoroughness as the researcher could manage. Furthermore, data collection was visually performed by using a multimedia notation program. The orthographic transcription and image capturing from the video were performed by using a multimedia notation program known as ELAN. The results of our transcription in the forms of utterances and images were given data codes conveying information on the data number, utterance, image, and table. These research data were then classified and analyzed based on the chosen topic, in this case, economy.

\section{Finding and Discussion}

\section{An Analysis of Utopian World}

The beginning of the story describes a unique habitant called Metro City. This city exemplify heaven that is floating in the sky. Then, there is also a city underneath Metro called the 
Surface. Staying in a Metro City is much better than living on The Surface because there are robots that do all human activities. Like the picture below, there is a narrative given by the narrator about the Metro city. The narrator stated that the Metro civilization is an ideal life that every human being yearns for. All things and activities can be done by the robot and remind important things.

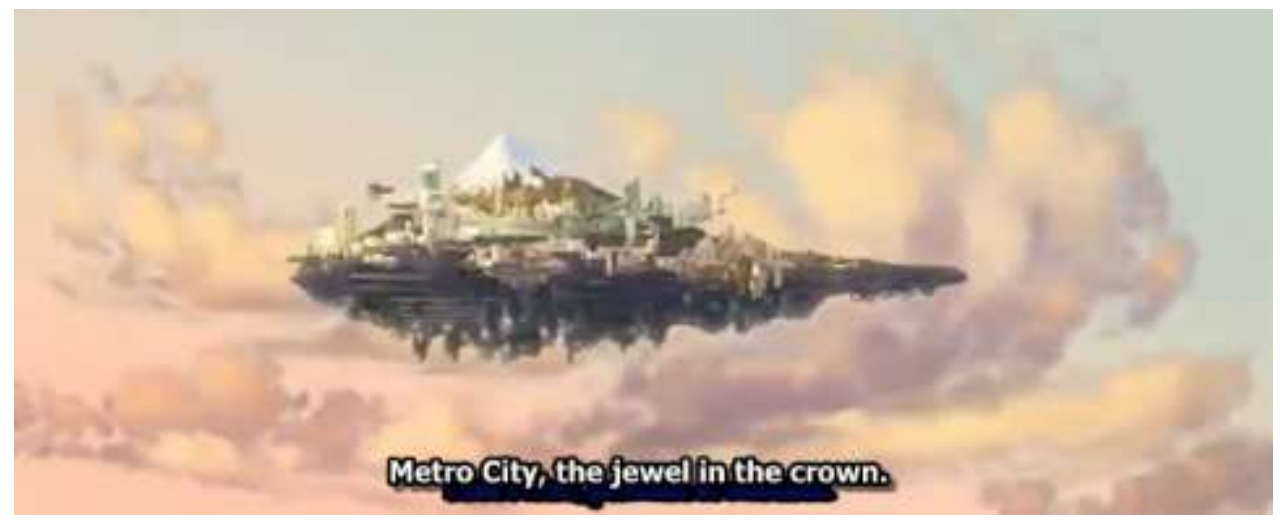

Fig. 1 Description of Metro City

The setting of Astro Boy presumably represents the utopian world. Utopian world is the idea of the perfect world, where there is no worries in living. Utopia is a name given to an imaginary land where everything is supposed to be ideal and perfect (Abdelbaky, 2016). The utopian setting aims for the equality and happiness. The book Utopia by Thomas Moore depicts an ideal place which was used ever since to define perfect societies wanted by people and promised by politicians.

Humans and Robot co-exist in this city. They are like friend that help each other. We can see the narrative in the image below. Humans in Metro City thank robots for their helping because they need robots for all conveniences of life.

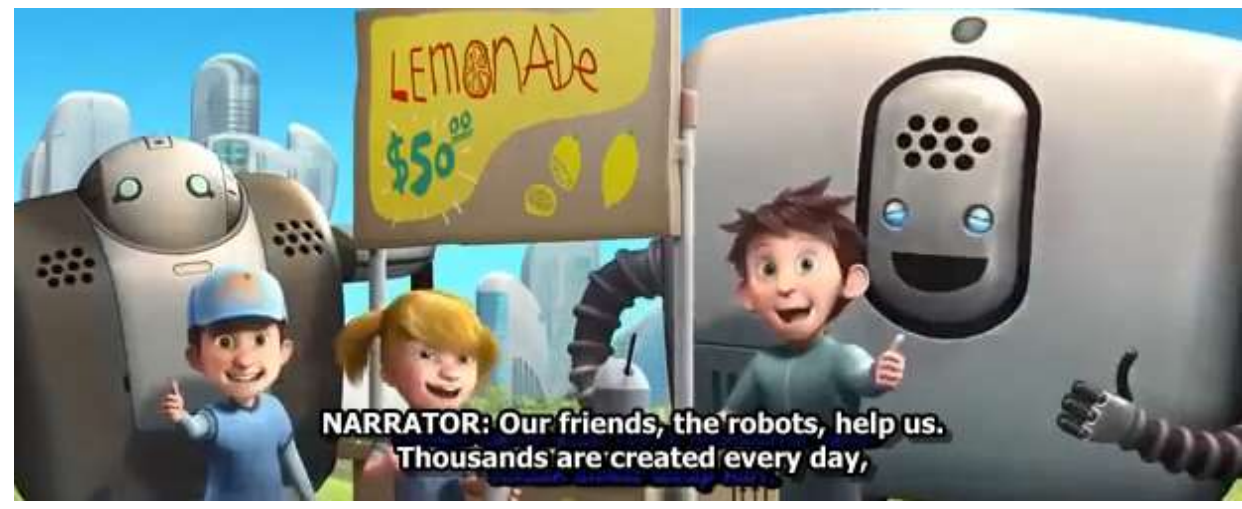

Fig. 2 Humans and Robots are friends

Metro City is described as a beautiful and perfect city. Everything feels delight and feels easy because of the help of the robot. They make robots as part of humans and are considered as friends. This can be seen in the first and second picture. People in Metro City feel very happy and helped by the robot. 
The utopian world that appears from human imagination gives happiness and equality for humans. Every human can have their own world and reach the satisfaction by their own imagination. We can achieve all the things that we can't do and the things we never get in real world. It all looks pleasant.

\section{The Non-Utopian Analysis}

The utopia actually only exists on human's imagination. Everybody wants a life like in a paradise, just want a peaceful and perfect life. It was never not found it in reality but could occurs in literary works. However, in Astro Boy, the one who only feels happiness is the human kind, while the robots are not. Since the human could enjoy their life and time, while the robots do their daily job. The utopian setting is only applies to the human kind and not for the robots. Moreover, the robots do not have any choices to speak up their mind, they are only working as they are being told to.

Astro Boy shows the differences between human kind as the master and the robots as the slavery. The robots only seen as the workers that doing what human told to them. In the beginning of the story, the narrator explain how the society happy when the robots work for them, the robots do their shopping, cook and serve their meals, take good care of the society, raising children, build the buildings, do everything that human won't do anymore (from the narrator of Astro Boy).

The robot as the slave, then the human kind defines as capitalist society. Because the human is subordinated to the laws of the market, in the movie the market uses robot as the slave and having their own laborers, which means that the human have their own laborers that is the robots. Moreover, what the human did to the robots is being called as "Enslaving the Robots", which means that the robots will always be their slave. So that human life will be much easier and they will feel happiness because everything is done by the robots. Hence, the utopian setting that is supposedly created by the author is only worked on the human kind, but not for the robots. It means that the setting that is supposedly utopian setting is fail, because there is slavery in capitalist life.

All robots used to do the human's work, in other words human doing nothing, everything is being prepare by the robots. Once the robots cannot be use, they are being thrown to The Surface, the other city. Then, as the slave, robots only hear what human told them to do, and human will never see the robots as the helpers. Furthermore, neither in the capitalist city called Metro City nor in the exile city called The Surface, the robots still become the slave of human being. There is the notion of oppression where the robots only live as the servant of human kind. It is because the robots is programmed to be voiceless, it means that even though technically they could defeat human kind with their energy, but the robots is being programmed to not harmed human kind even though they are treated in badly by human. Then, human could harmed them by deactivated their system and throw them to The Surface as they are no longer can serve human properly, while the robots not allowed to harmed the human, which is mean that the robots will always be human's slave.

Another notion that the setting is not utopian is because there is classism in the movie. Capitalism creates classism that is where the social gap comes in to the society. Classism refers to the marginalization, derision, alienation, and discrimination of a group of peoplembased upon their perceived social or economic standing (Choi \& Miller, 2018). The owner and people from middle-class will be seen as the dominant group member and the smartest, while the working class will get oppressed because of their class. In the movie, the robots are seen as the working 
class, while the human are the dominant. That is why there is slavery, because the human could control the robot and make them as the slave.

Furthermore, there are two cities as the setting, called Metro City and The Surface. Metro City is the floating city, where everything is about happiness. Human life all much easier, all they can do is gain benefit by exploit the robots. Meanwhile, The Surface is a poor city, where the robots are only the outcast robots from Metro City. But still the notion of slavery happened in both cities.

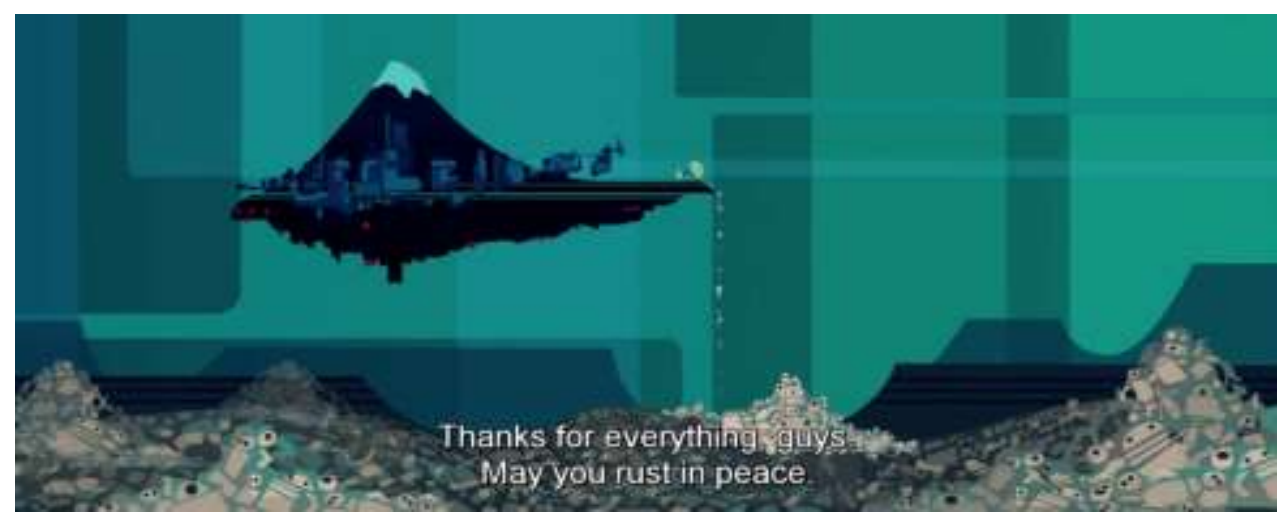

Fig. 3 Metro City and The Surface

Through the screenshot, the upper and floating place is the Metro City, where all rich people, good and perfect robots are live. While at the below is The Surface, where there is only poor people and robots that already broken. The robots that could not be use is being thrown to The Surface, it looks like The Surface is the trashcan for Metro City society. Moreover, people from The Surface could not get into Metro City, because they are not allowed to come. Metro City society will not accept people or robots that come from The Surface because society in Metro City has a rule that no losers from The Surface come to Metro City. Besides, the way people from the Metro City throws their unused robot to The Surface also explain that people from a higher place still could go down, while people from the lower place will never go up, because the place is high and there is no way to go up without technology. It shows that people from the lower class will never been change their class into the upper class. They will always be in the lower class.

Furthermore, the hierarchy is clearly shown because there is binary opposition between the two cities. The first is the portrayal of the city itself. Metro City that is describes as rich and civilised, where technology and modernity is developed, is place above The Surface. Which is meant that society in Metro City higher than society in The Surface. Moreover, the portrayal of the society is shown through the children. During in the Metro City, when Toby is still alive, the children are going to school and all of them are incredibly smart, they also know how to behave, and their clothes also reflecting their class. Meanwhile in The Surface, the children are wild, uncivilised, and they do not know how to read. They never been in school and do not how to behave. Furthermore, the society in Metro City could throw their unused robots to The Surface. Moreover, the condition of the city is totally different. Metro City is described as modern and beautiful, while The Surface is the opposite. Furthermore, people who are not incompatible for the city will be thrown to The Surface. It shows when one technician that is used to work in Metro City was get fired and he has to go to The Surface because he is no longer being use by Metro City. 
Another notion that the setting is non-utopian setting is come from Astro. His feeling about unhomeliness because he could not fit in to the new society, and he is being expelled by his creator, that is his father. Moreover, the notion of unhomeliness in Astro Boy is about the anxiety between being a human and more than human, being the original or only a piece of art or copy which is create the feeling of does not know where to belong and could not fit in to the new land. Because of the memory of Toby Tenma that is being programmed to the robot's body, Astro has no idea that he is a robot, because he lives as Toby. After he knows that he is a robot, he still has uneasy feeling because he has human's heart and feeling, unlike the other robots that only do what human told to them. The uneasy feeling comes in because he does not know where to go, he could not be accepted in his own home and friends because he is a robot and only a copy of Toby Tenma, yet he also feel could not fit in among the robots because he has human memory.

The idea of utopian setting is not working on Astro, because he is not happy with his condition. Since he is different whether neither as a human nor as a robot. It makes him does not know where to belong, he does not feel belong to Metro City, a city that supposedly full of happiness, yet he also does not feel belong to The Surface because he is different than the society in The Surface.

Next is the other concept that makes the setting of Astro Boy is non-utopian setting is because of othering. Utopian setting supposedly about equality, there is no othering, slavery, and classism. However, in Astro Boy, even though the setting of the movie offered about happiness, but the author still could not avoid othering in the movie. The othering is between human kind and the robots, and also society in the Metro City and The Surface. In this concept also shows how the robots got doubly oppression, they are being oppressed as the robot and as a part of the society of The Surface.

About The Self and The Others in the movie, Julia Kristeva discussed about abjection in the animation, it is the process by which we become the subject and "human" (McAfee, 2004). Meaning that the process by which acceptable forms of subjectivity and sociality are constituted. The abject is that which is expelled and is literally rendered "other" or "not me." Thus the abject as other functions as a kind of border that maps the boundaries of the self and the proper. However the abject is a complicated, ambiguous kind of border because, although it lies outside, it remains a constant threat (Bouldin, 2004). From the quotation it can be define that the othering in the movie is about the human kind and the robots. It is about how the robots can be seen as the abjection, that trying to be the subject and human, but they are being seen as the other, since they are actually the object. And the self is the human kind who creates the robots and uses them as the servants.

As the self, human kind gets everything that positive and powerful. Human kinds are the smartest, civilised, the master, and the creator, while the robots as the other are not same as the human. They are the creation, the servants, and could not befriend with the human being. It shows when Astro wants to play with the robot, but his father forbid him by saying that the robots should do their thing. It means that the robots as the other, could not sit together with human. Moreover, the robots has called the human as "master", it shows the superiority of human being as the self. They create the robots and make them believe that the human are their true leader and their master, hence they have called the human as "master". 


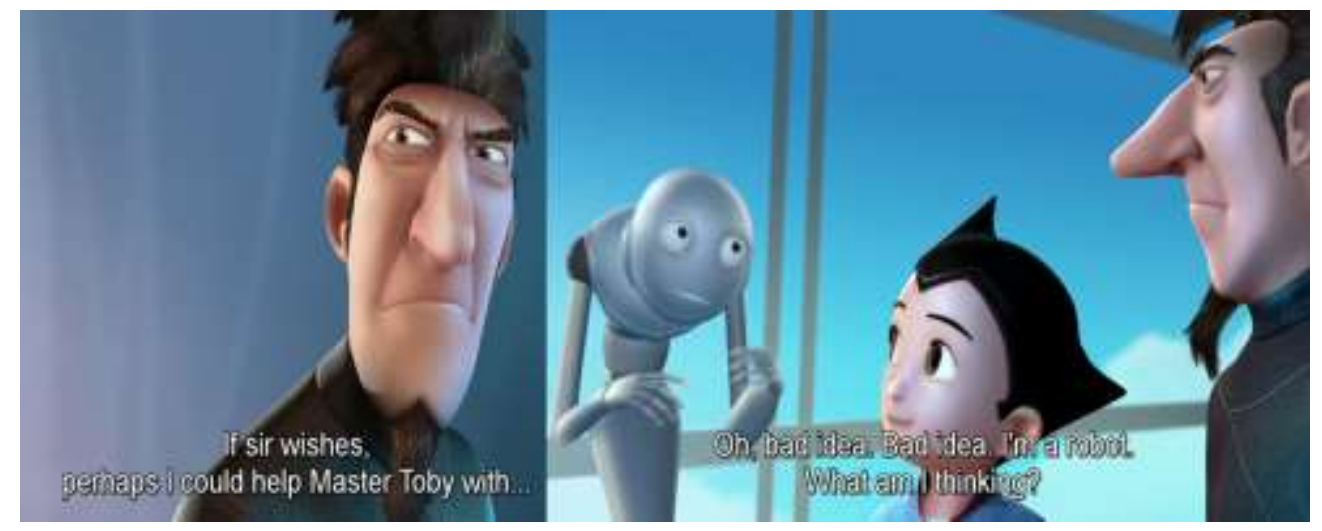

Fig. 4 Master and Robot

Moreover, in the movie, the distinction between the self and the others is clearly shown through the human's attitude. As seen from the screenshot above, it shows how the robots could not mingled to the human. When the robot offer to help human, the human look into it as if the robot already being rude because it tried to step into human's activity. As explain before, the robot is human's slave, they only work what the human told them to do, which means that the robot could not have any idea above the human's idea, since they are being oppressed under the human's authority, because the human more superior than the robot.

Another kind of othering is that the robots could not act like the human. It means that even though the robots work, talk, walk, and doing whatever human do, they are still not be the same as the human and not allowed to be the same as the human. It shows when the robot that is a servant of Toby use Toby's hat, and the professor got angry because it uses Toby's hat, just because it is a robot.

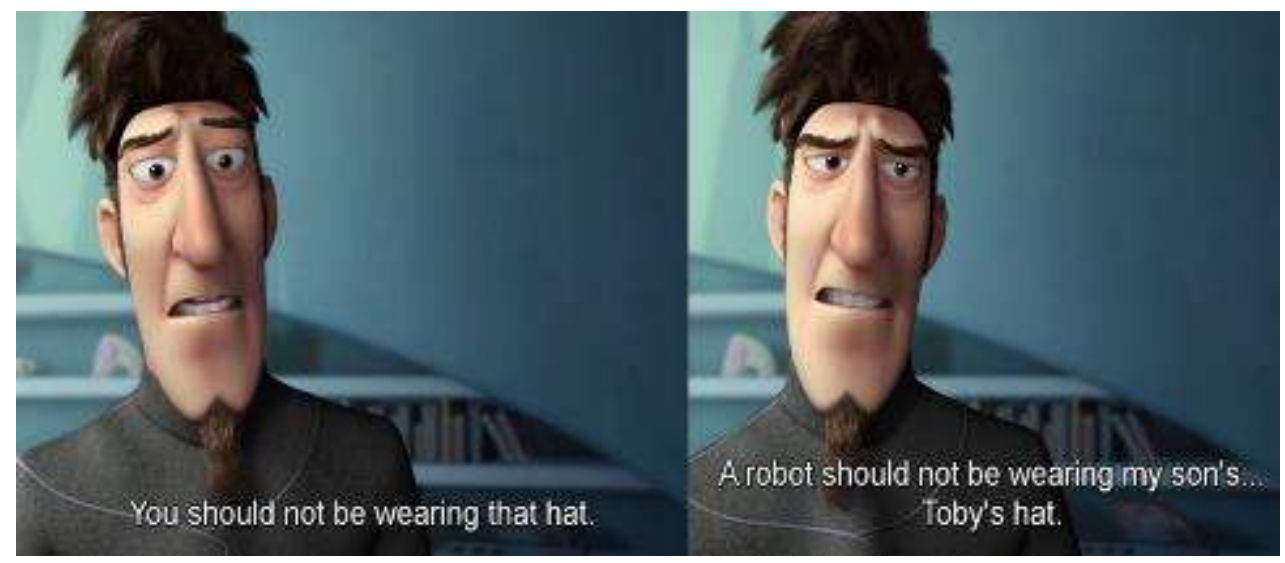

Fig. 5 Dr. Tenma

Furthermore, other than the robots, there is also othering between the human. That is society in Metro City and society in The Surface. Besides showing about classism, the rule about no losers from The Surface come to Metro City also showing that the society in the Surface that referred as the loser is the other, while society in Metro City is the self. It shows how society in Metro City throws their unused robot to The Surface. Moreover, the notion of the other and the self between the human also seen when people from The Surface admiring people from the Metro 
City, while people from the Metro City never knows and never care about people in The Surface. It shows the superiority of people in Metro City that could not be imitate by people from The Surface, it makes people from the Surface only could seeing the Metro City from below, while people in Metro City will never look The Surface.

As the end of the story, the author demonstrates the equality between The Surface and Metro City, and also there is no slavery for the robots, because the robot is allowed to go whenever they want and no longer call the human as master. Since the story is supposedly for children, then as popular culture, the movie is created by having a happy ending. The moral lesson still being shown by changing people mindset about the robot, where there is no slavery, and also because the Metro City is fell to The Surface, no longer floating in the air, it makes the cities become one. It is also the symbol of equality, where there is no the upper and the lower class, and people from The Surface could go to Metro City as the screenshot below shows.

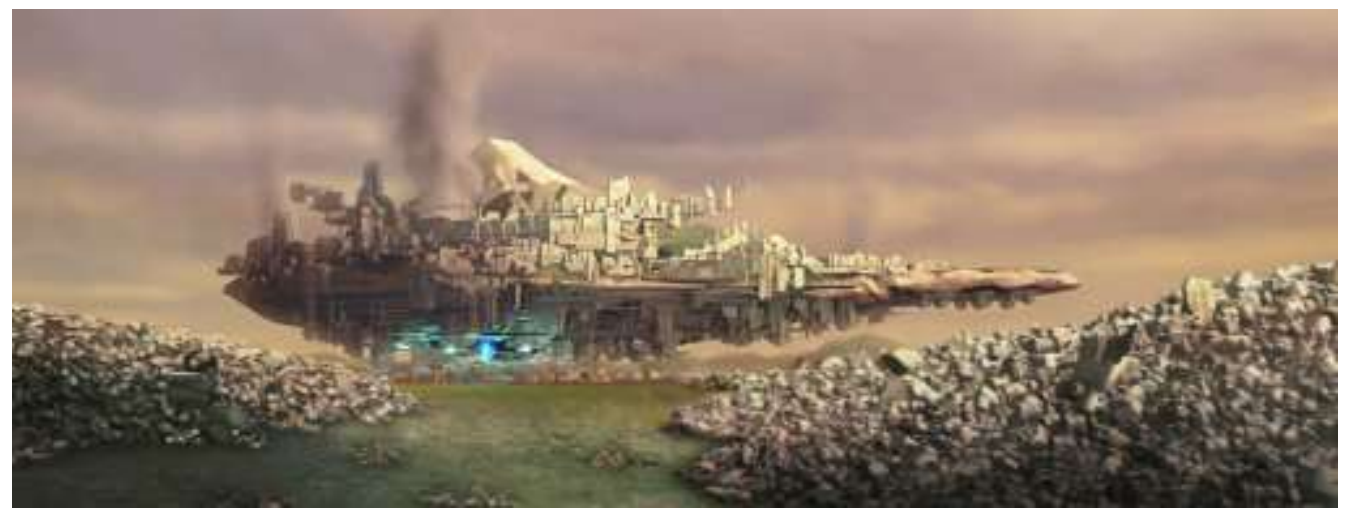

Fig. 6 Metro City falls down

In every condition, robots always be the slaves, both in Metro City and The Surface. Whereas, robots are presented to help human activities. Humans should take care of the robots too. In the story, the robot is depicted as having human-like properties but the treatment that they get is not fair to them. Therefore, there is a need for human to consider what they have to do to other creations because robots also need good treatment from humans.

\section{Conclusion}

Based on the previous analysis, it may be regarded as certain the setting of the Astro Boy is actually non-utopian setting. Even though it is supposedly create the utopian setting since it is about happiness and how live properly without worries. The author makes the robots to help the human so that the human will only live happily and having an easy life. However, the utopian setting is only worked on the human, not for the robots. Even it only worked for a few human, that is human who live in the Metro City. As for the robots, they only created to be the slave of human being. They are working and do what the human told them to do, even though it is about a devil job such as become a villain, which meant that the robots do not have any rights to choose what they want to do or even refuse what human told them to do.

Furthermore, the setting is categorized as flawed utopian because there is the notion of slavery, unhappiness, inequality or hierarchy, and othering. Since people in the Metro City are the capitalist society, they create the social gap between The Surface and Metro City. Then, there is the notion of inequality, because the life between the societies in The Surface is not 
the same as the society in Metro City. Moreover, there is slavery, where the robots are seen as the human slave, and even there is the program of enslaving the robots. In order to reach their happiness, human need to make the robots worked for them. After that, the notion of unhappiness is comes from the feeling of unhomeliness by Astro, because he does not know where to belong. Then, what makes the setting is non-utopian is because there is othering and oppression between the human, that is the society from Metro City as the self and society from The Surface as the other, and also the robots, that is the human as the self and the robots as the other.

However, as the popular culture, the target of movie is supposed for children. The moral lesson is teaching about equality, then that is how the creator create the utopian world. Because in the end, the professor (the creator of the robots) freed the robot by letting the robot called him only by his name. Moreover, the society now looks the robots properly after Astro saved their life. Hence, in the end, after Metro City becomes one with The Surface, and the professor freed the robot, the author succeed in creating utopian setting where there is equality and happy ending.

\section{References}

Abdelbaky, A. (2016). A Perfect World or an Oppressive World: A Critical Study of Utopia and Dystopia as Subgenres of Science Fiction. Smart Moves Journal Ijellh, 4(3), 17. https://doi.org/10.24113/ijellh.v4i3.1201

Astro Boy Movie. (2009). Youtube. Available from https://www.youtube.com/watch?v=OuWGQFC-cD8

Bouldin, J. R. (2004). The Animated and The Actual: Toward a Theory of Animation, LiveAction, and Everyday Life. Dissertation University of California Irvine.

Choi, N. Y., \& Miller, M. J. (2018). Social Class, Classism, Stigma, and College Students' Attitudes Toward Counseling. The Counseling Psychologist, 46(6), 761-785. https://doi.org/10.1177/0011000018796789

Dooly, M., \& Moore, E. (2017). Introduction: qualitative approaches to research on plurilingual education. Qualitative Approaches to Research on Plurilingual Education / Enfocaments Qualitatius per a La Recerca En Educació Plurilingüe / Enfoques Cualitativos Para La Investigación En Educación $\quad$ Plurilingüe, $1-10$. https://doi.org/10.14705/rpnet.2017.emmd2016.618

Jahan, S., \& Mahmud, A. S. (2015). What is capitalism?: Free markets may not be perfect but they are probably the best way to organize an economy. Finance and Development, 52(2), 44-45.

Leiwakabessy, A. C. (2020). Analysis Of Capitalism In The Novel “ The Great Gatsby" By F Scott Fitzgerald ( Sociology of Literature Approach ). Journal of Advanced English Studies, $3(2), 78-86$.

Moore, T. (2017). Utopia. North Charleston, SC: Createspace Independent Publishing Platform.

Parra, C., \& Walsh, C. (2016). Introduction Socialities of Nature Beyond Utopia. 11(3), 229-238. https://doi.org/10.3167/nc.2016.110301

Qin, B. (2017). Analysis of "Utopia" Narration in Verne's science fiction. Atlantis Press, 119(Essaeme), 1830-1834. https://doi.org/10.2991/essaeme-17.2017.377

Scambler, G. (2019). Sociology, Social Class, Health Inequalities, and the Avoidance of "Classism." Frontiers in Sociology, 4(July), 1-4. https://doi.org/10.3389/fsoc.2019.00056

Takagi, M. (2020). Japanese Society: Where Humans and Robots Coexist. International Journal of Social Science and Humanity, 10(1), 13-16. 
https://doi.org/10.18178/ijssh.2020.v10.1006

Yuliani, W. (2018). Metode Penelitian Deskriptif Kualitatif Dalam Perspektif Bimbingan dan Konseling. Quanta, 2(2), 83-91. https://doi.org/10.22460/q.v2i2p83-91.1641 